\title{
The "smart city" concept as a strategy for managing the infrastructure of a single-industry town
}

\author{
Kymbat Kunanbaeva ${ }^{1,{ }^{*}}$, Saule Rahimova ${ }^{2,3}$, Aleksey Titkov ${ }^{2}$, and Lyudmila Goncharenko ${ }^{3}$ \\ ${ }^{1}$ Financial University under the Government of the Russian Federation,49, Leningradsky,125993, \\ Moscow, Russia \\ ${ }^{2}$ S. Toraighyrov Pavlodar State University, 64, Lomov Str., 140008, Pavlodar, Kazakhstan \\ ${ }^{3}$ Plekhanov Russian University of Economics, 36, Stremyannyy Pereulok, 115093, Moscow, Russia
}

\begin{abstract}
The paper is devoted to topical issues of the formation and development of an effective economic policy for managing the infrastructure of a single-industry town with the priorities of using the "smart city" concept. The purpose of the paper is to form a system of integrated management tools for the strategic development of a singleindustry town, taking into account modern digitalization mechanisms of socio-economic systems. Particular attention is paid to the diversification of the development of single-industry towns, from revising the emphasis of the economic role from city-forming enterprises to small and mediumsized businesses, social sphere of single-industry towns, sectors of the economy focused on human resources and human capital. The main research methods were comparison, analogy, analysis and synthesis, systematic approach, forecasting method, induction and deduction methods, statistical method, hypothesis design method. The results of scientific research can find practical application at regional levels in the development of strategic programs for the development of single-industry towns, which are focused on the application of innovations and new technologies.
\end{abstract}

\section{Introduction}

Modern economic systems are built on the principles of territorial distribution and concentration, while a special economic role is assigned not only to megacities, large and medium cities, but also to small urban areas with adjacent territories.

The structure of the economy of small towns and surrounding areas often does not correspond to modern advanced requirements of a market economy. So, for example, in the practice of the economies of the Russian Federation and the Republic of Kazakhstan, many of the small towns have a single-industry economic structure for a long period of time, which gives the status to small towns - single-industry towns. The industry of such towns is characterized by a low level of technological development, the development of small and

\footnotetext{
${ }^{*}$ Corresponding author: doptaganka@yandex.ru
} 
medium-sized businesses, and demographic attraction. As a result, the economic systems of single-industry towns and the adjacent territorial districts demonstrate low competitiveness.

Urban infrastructure in single-industry towns - roads, utilities, housing, educational, scientific, cultural, medical institutions, also have high reserves for improvement and development. They have a low level of socio-economic activity in the conditions of innovative development of market relations.

At the same time, world practice shows and demonstrates examples of successful solutions to the socio-economic problems of single-industry towns and territories adjacent to them. There are single-industry towns which, due to the high quality of management (and, above all, development management), have managed to achieve a significant improvement in the quality of life of the population, involving human resources in intensively developing small and medium-sized businesses.

Models for managing the development of single-industry towns, emerging in practice, require continuous improvement due to constant changes in the external environment. In modern conditions, it is necessary to develop new managerial approaches aimed at restoring the abilities of single-industry towns and adjacent territorial districts for independent development and improving the quality of life of the population.

A number of strategic priorities for the development and management of socioeconomic systems of single-industry towns can be focused on digitalization of the main subsystems of infrastructure development, which subsequently will receive the status of a "smart city".

\section{Study}

At the present stage of development, about $10 \%$ of the population of Russia live in singleindustry towns, the socio-economic development of which is closely connected with the only town-forming organization or a group of organizations integrated among themselves. The number of single-industry towns today totals 319, of which 227 single-industry towns belong to the Ministry of Industry and Trade of Russia [1]. A large number of singleindustry towns are preserved on the territory of the Republic of Kazakhstan. Of the 86 cities of the republic, 27 , or one in three $(32 \%)$, have the status of a single-industry town. According to modern classification, urban settlements that have from 10 to 200 thousand inhabitants, in which at least $20 \%$ of the adult population works at a town-forming enterprise, are recognized as single-industry towns in the Republic of Kazakhstan. Only 4 monotowns of the republic have a population of over or about 100 thousand (Temirtau, Rudny, Ekibastuz, Zhanaozen), and the population of the rest does not exceed 50 thousand people [2].

Single-industry towns, both in the Russian Federation and in the Republic of Kazakhstan, are characterized by a number of systemic, socio-economic problems presented in Figure 1.

Resources and modern support measures aimed at the development of single-industry towns are aimed at reducing dependence on the development of town-forming organizations, creating conditions for the development of small and medium enterprises, and improving the urban infrastructure of single-industry towns.

In the Russian Federation, in the framework of the special-purpose approach to management, the following projects are implemented in single-industry towns:

- creation of territories of priority development;

- ensuring balanced budgets through subsidies;

- implementation of the programs of the Monotown Development Fund and the Industrial Development Fund; 
- creation and development of infrastructure to support small businesses (business incubators, industrial parks, other elements);

- subsidizing part of the cost for paying electric energy (power) [3].

One of the last areas of support provided by the Monotown Development Fund is the project on mentoring "MONOGORODA.RF". So, for example, within the framework of the agreement, the mentor cities of Novokuznetsk and Suzdal will help Kameshkovo in solving problems that are urgent for a single-industry town. In particular, they will share their experience in attracting people to the implementation of projects to form an urban environment, and talk about attracting small and medium-sized businesses to procurement activities, as well as about the organization of social and leisure activities for older people. In addition, cities will assist in the implementation of best practices for the development of the urban economy. Nowadays, the Monotown Development Fund has already signed several mentoring agreements between monotowns. Among them are Kotovsk, Tambov Region, and Kuvshinovo, Tver Region, Tutaev, Yaroslavl Region, and Novomichurinsk, Ryazan Region. Nevinnomysk of the Stavropol Krai became the mentor of three singleindustry towns at once - Kovdor of the Murmansk Region, Segezha and Nadvoits of the Republic of Karelia. In total, it is planned to sign about 20 such agreements with cities from the TOP 10 leaders of the rating of single-industry towns.

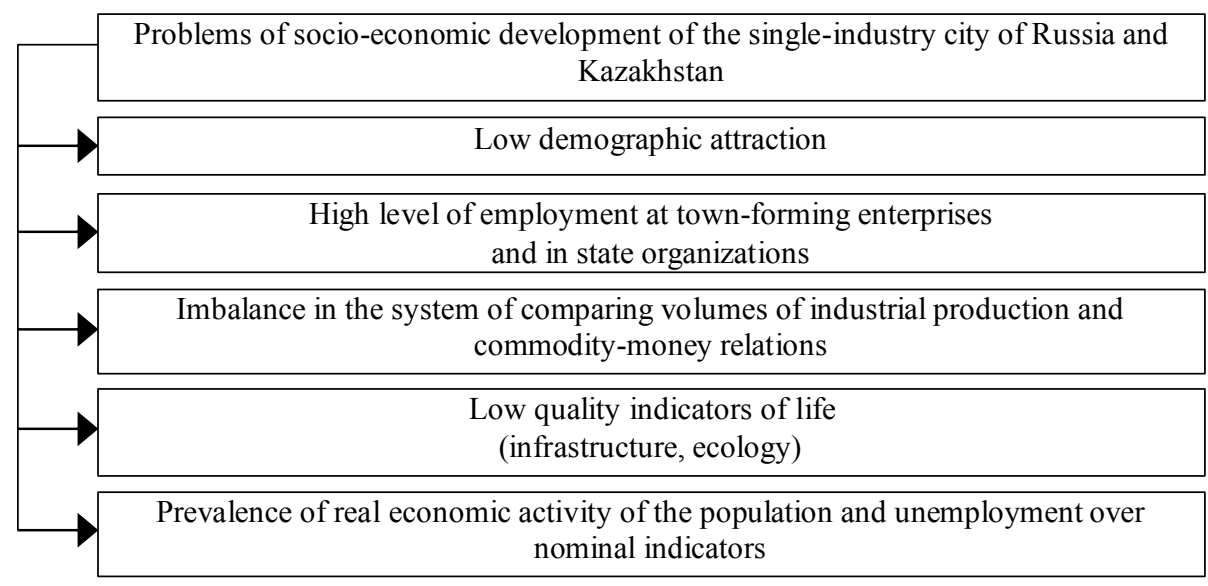

Fig. 1. Systemic problems of socio-economic development of single-industry towns of Russia and Kazakhstan (Created by the authors).

The implementation of projects for the development of single-industry towns contributed to the creation of 244.5 thousand jobs in single-industry towns, of which 144.4 thousand were permanent. As of 2018, 66 priority development areas were created, where 9 thousand jobs were created, about 280 residents, 15 billion rubles of investments were attracted, 2.5 billion rubles of taxes and various contributions were paid [4].

For the development of single-industry towns in the Republic of Kazakhstan, the State strategic program "Development of single-industry towns for 2012 - 2020" has been adopted. The main objectives of the program are concentrated in the following areas: optimization of single-industry towns depending on production capacity of stable working enterprises; diversification of the economy and the development of small and medium-sized businesses to ensure the optimal structure of employment for single-industry towns; increasing the mobility of labor resources in single-industry towns, stimulating voluntary relocation to settlements with high potential for socio-economic development and centers of economic growth; development of social and engineering infrastructure of single-industry towns based on optimal population. The program focuses on such important target indicators as a 4-fold increase in active operating small enterprises, a decrease in 
unemployment to a level of no more than 5\% [5].

The current stage of development of single-industry towns is focused on diversifying the economy and creating a comfortable infrastructure for city residents.

Management of the socio-economic system of single-industry towns can be intensified through the use of digitalization technologies.

The modern world agenda determines the development of the digital economy, opportunities in the digital area are rapidly expanding, and the fourth industrial revolution is being implemented. Digitalization penetrates the branches of the traditional economy, and also becomes a part of everyday life. On February 1, 2019, during the international forum "Digital agenda in the era of globalization 2.0. Innovation Ecosystem of Eurasia", the EAEU member countries discussed the main issues on the development of joint measures to accelerate the development of the digital economies of the EAEU countries, increasing their competitiveness. Chairman of the Government of the Russian Federation D. Medvedev noted that the digital program is a national model, a national program, which provides for the creation of all ecosystem components for the growth of the digital economy $[6,7]$.

The driver for the development of the digital economy and increasing the level of implementation and use of "smart" technologies is the implementation of the "smart city" concept, which allows integration of information and communication technologies to optimize the life of the city and manage urban property. In the context of global transformation, the concept of "smart city" is a comprehensive digitalization tool whose task is to create an infrastructure based on intelligent networks.

Nowadays, the growth of information and communication technologies in the country determines the implementation of the "smart city" concept. Thus, an analysis conducted by the Research Institute of Technology and Communications identified the top 10 smart cities in Russia, which were identified by 26 key features [8-11].

The concept of "smart city" as an effective system for creating the infrastructure of a city is relevant in single-industry municipalities (single-industry towns). In 2018, as part of the All-Russian Investment Forum in Sochi, during the session "Monotowns - planning the future", it was noted that a new block on improving state and municipal governance will be introduced into the program "Digital Economy". This will contribute to the formation of effective teams in monotowns, including through the use of new technologies, and in conjunction with teams trained under the program of the Monotown Development Fund [4].

Thus, it can be said that the concept of "smart city" can be included in the basis of the program for the integrated development of single-industry towns as a strategy for managing the infrastructure of a single-industry town.

Within the concept of "smart city", the fundamental principle based on the concept of the Internet of things is the introduction of information technologies in the urban infrastructure, which will contribute to improving the management system and interaction of government bodies with the population, improving the quality and efficiency of urban services [12-21]. The main asset of the company will be people, processes and technologies. The implementation of the "smart city" concept will also help to attract highly qualified personnel, reduce the outflow of youth from a single-industry town, and increase the population of the city.

\section{Conclusions}

In order to digitalize the economic system of a single-industry town and design a "smart city" in the future, the model shown in Figure 2 can be taken as a basis.

The general concept of the "smart city" single-industry town can be based on the following infrastructure approach: 
- creation and functioning of the innovative and industrial zone;

- creation and functioning of service and technology sectors (business incubator, engineering center, technology park, HR recruiting center, logistics center-HUB);

- creation and functioning of the IT-data center;

- creative reform of social infrastructure.

As a result, "smart city" is an intelligent cluster based on the digitalization of all its elements and their digital interaction. In general terms, the concept of "smart city" can be represented in accordance with Figure 3.

It should be noted that, with all other things being equal, the concept of "smart city" consists not only in the comprehensive digitalization of all processes in the life of a singleindustry town, but also in the innovative functioning of "smart infrastructure".

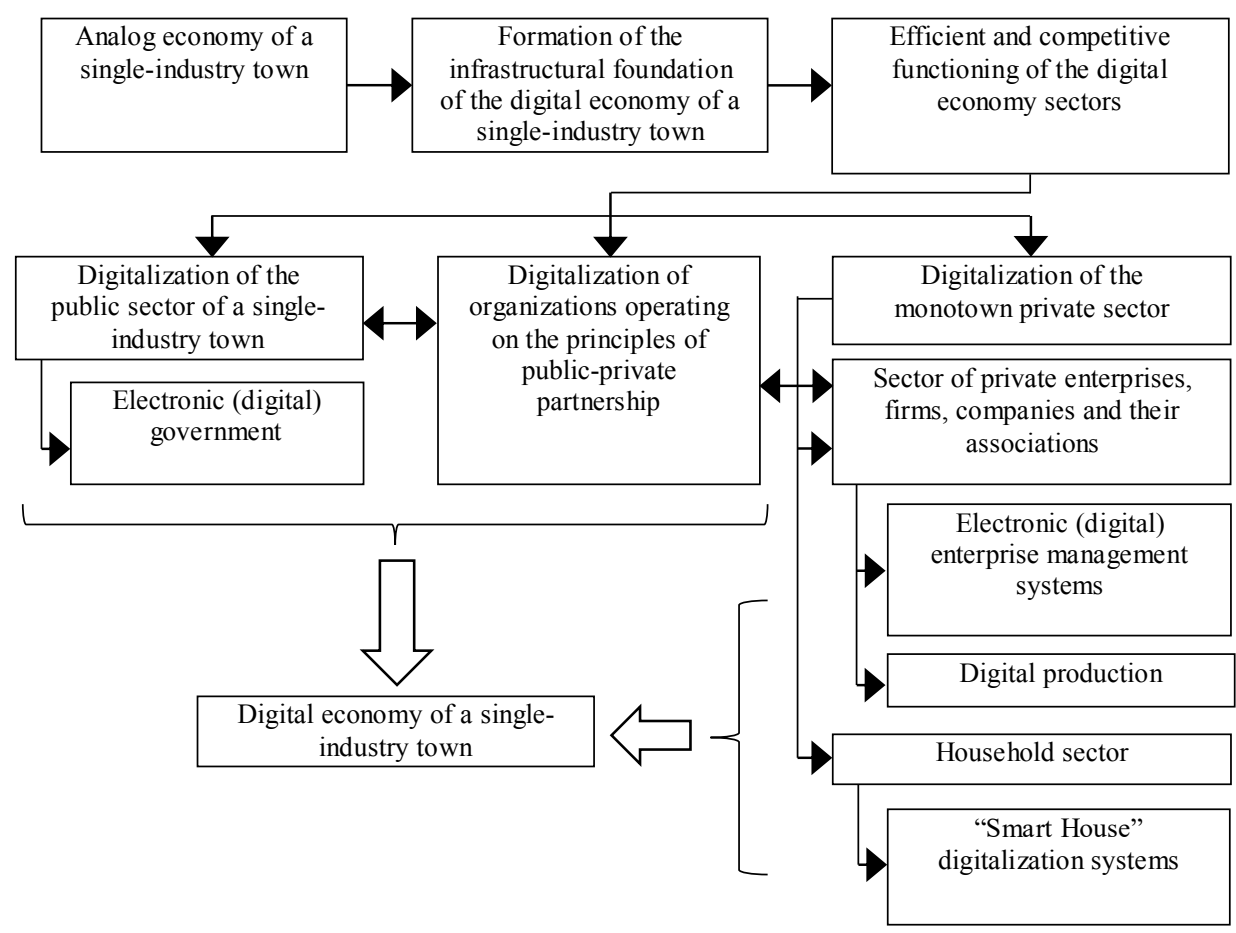

Fig. 2. Methodology of transformation from the traditional-type economy of a single-industry town to a digital economy [9]. 


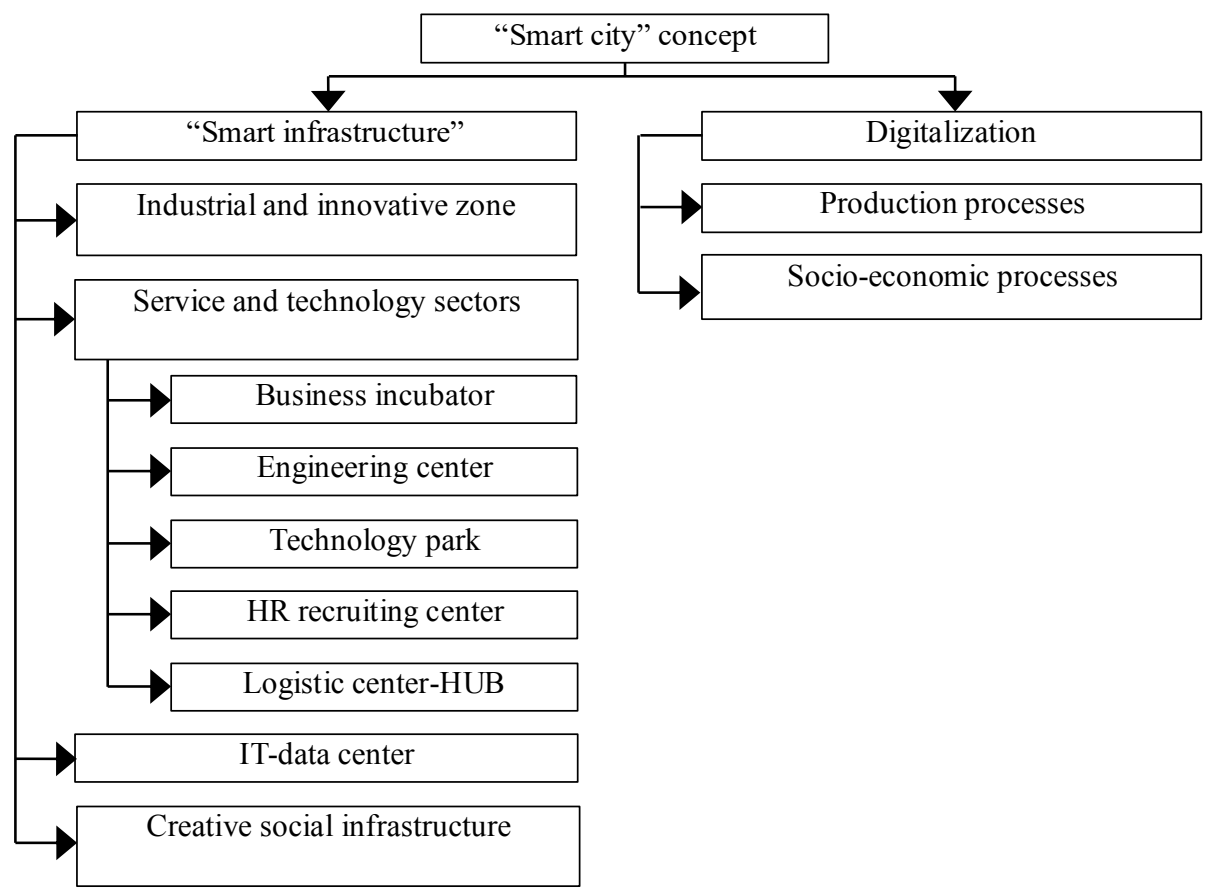

Fig. 3. The concept and main subsystems of a "smart city" (Created by the authors).

In this formation, the concept should create optimal fundamental basis for the emergence of post-industrial sectors focused on creating products with high added value. A significant role in this aspect should be assigned not to town-forming enterprises, but to small and medium-sized businesses that operate on the principles of smart technologies and the economy of impressions.

The global development trend of the "smart city" concept shows that the number of such cities in the predicted time dynamics will increase. For example, according to the forecast of experts of the McKinsey consulting corporation, the number of "smart" cities, in the global aspect, will reach about 600 by 2020, which in 5 years will accumulate about $67 \%$ of world GDP. The Arup consulting company estimates the world market of "smart" city services by 2020 at a rate of $\$ 400$ billion per year.

The concept of a "smart city" in single-industry towns is a strategic course that requires an integrated approach to operation, planning, networking and urban infrastructure management in order to provide citizens with a higher quality of life when solving urban energy, environmental, economic, and social problems.

As a result, the Russian Federation and the Republic of Kazakhstan must follow global trends in the area of reforming the economy management systems of single-industry towns in order to maintain the competitiveness of national production forces.

\section{References}

1. The main results of the work of the Ministry of Industry and Trade of the Russian Federation in 2016, http://government.ru/dep_news/27324/

2. Monotowns of Kazakhstan, https://ru.wikipedia.org/wiki/

3. A.Mottaeva, A. Borisova ,E3S Web of Conferences 138, 02015 (2019) https://doi.org/10.1051/e3sconf/201913802015 
4. The program for the integrated development of single-industry towns will cover new areas in 2018, https://governors.ru/news/Programma-kompleksnogo-razvitiyamonogorodov-v-2018-godu-okhvatit-novye-napravleniya/116626

5. On approval of the Program for the development of single-industry towns for 20122020,https://tengrinews.kz/zakon/pravitelstvo_respubliki_kazahstan_premer_ministr_r k/hozyaystvennaya_deyatelnost/id-P12000006-63/

6. The Heads of Government of the EAEU countries discussed the development of the innovative ecosystem of Eurasia at the forum "Digital Agenda in the era of globalization 2.0.", https://www.nitec.kz/story/glavyi-pravitelstv-stran-eaes-obsudilirazvitie-innovatsionnoy-ekosistemyi-evrazii-na-forume-tsifrovaya-povestka-v-epohuglobalizatsii-20

7. N.A. Kharitonova, E.N. Kharitonova, V.N. Pulyaeva, Advances in Intelligent Systems and Computing 726, 1091-1100 (2019)

8. A. Mottaeva, N. Kalinina, A. Kuzmina, O. Olenina and A. Glashev, E3S Web of Conferences, 91,08072, (2019) doi.org/10.1051/e3sconf/20199108072

9. E. Beisembay, Vestnik of the Karaganda University. Series "Economics" 4(96), 207 219 (2019)

10. Ya.E.Begich, P.A. Sherstobitova, Construction of unique buildings and structures 8(59), 27 - 40 (2017)

11. L. Akhmetshina, T. Pokrovskaya, D. Semernin, MATEC Web of Conferences 193, 05047 (2018) https://doi.org/10.1051/matecconf/20181930504

12. L. Akhmetshina, A. Sergeev, A. Mottaeva, E3S Web of Conferences 91, 06008 (2019) https://doi.org/10.1051/e3sconf/20199106008

13. K. Kunanbayeva, A. Gorovoy, A. Butyrin, MATEC Web of Conferences 193, 05048 (2018) https://doi.org/10.1051/matecconf/201819305048

14. S. Rakhimova, K. Kunanbayeva, L. Goncharenko, A. Pigurin, E3S Web of Conferences 110, 02154 (2019) https://doi.org/10.1051/e3sconf/201911002154

15. I.A. Markina, A.V. Sharkova, M.Y. Barna, International Journal of Entrepreneurship 22(3) (2018)

16. I.A. Markina, A.V. Sharkova, Journal of Applied Economic Sciences 9(4), 687-693 (2014)

17. O. Kalinina, V. Suschenko, V. Shchegolev, S. Barykin. Proceedings: MATEC Web of Conferences. Volume 193. P. 05063. (2018) DOI: $10.1051 /$ matecconf $/ 201819305063$

18. S. Barykin, A. Kobicheva. Proceedings: MATEC Web of Conferences. Volume 170. P. 01020. (2018) DOI: 10.1051/matecconf/201817001020

19. I. Krasyuk, Y. Medvedeva, V. Baharev, G. Chargaziya. Proceedings: IOP Conference Series: Materials Science and Engineering. P. 012124. (2019) DOI: 10.1088/1757$899 X / 497 / 1 / 012124$

20. I. Krasyuk, T. Kirillova, V. Bakharev, B. Lyamin. Proceedings: IOP Conference Series: Materials Science and Engineering. P. 012125. (2019) DOI: 10.1088/1757$899 X / 497 / 1 / 012125$

21. S. Bozhuk, N. Krasnostavskaia, N. Pletneva, T. Maslova. IOP Conference Series: Materials Science and Engineering. 497 (1). P. 012. (2019) DOI: 10.1088/1757899X/497/1/012115 